\title{
A Comparative Multicenter Study on the Epidemiology of Traumatic Fractures During the COVID-19 Early Emergency Response Period in Yogyakarta Special Region, Indonesia
}

Luthfi Hidayat ( $\nabla$ luthfi.hidayat@ugm.ac.id)

Faculty of Medicine, Public Health, and Nursing Universitas Gadjah Mada

Bernadeta Fuad Paramita Rahayu

Faculty of Medicine, Public Health, and Nursing Universitas Gadjah Mada

Rosyad Nur Khadafi

Faculty of Medicine, Public Health, and Nursing Universitas Gadjah Mada

Acep Eko Budi Purwanta

Wates Regional Public Hospital

Marda Ade Saputra

Yogyakarta Regional Public Hospital

Eko Sumardiyono

Wonosari Regional Public Hospital

Aditya Fuad Robby Triangga

Faculty of Medicine, Public Health, and Nursing Universitas Gadjah Mada

Research article

Keywords: COVID-19, epidemiology, trauma, fracture, Indonesia

Posted Date: February 23rd, 2021

DOI: https://doi.org/10.21203/rs.3.rs-257599/v1

License: (c) (i) This work is licensed under a Creative Commons Attribution 4.0 International License. Read Full License 


\section{Abstract}

Background: The changes of lifestyle and mobility during the Coronavirus Disease 2019 (COVID-19) pandemic may influence the epidemiology of traumatic fractures. This study aimed to investigate the epidemiology of traumatic fractures in Yogyakarta Special Region (Daerah Istimewa Yogyakarta/DIY) during the COVID-19 emergency response period and compare the data with the similar period in the previous year.

Methods: This was a retrospective study involving five secondary referral hospitals and one tertiary referral hospital. We included all patients who presented to the emergency departments or orthopedic clinics who were then diagnosed with new onset fractures. We compared the data during the emergency response period (COVID group) with a similar period in 2019 (control group).

Results: There were 1,249 patients with 1,428 fractures included in this study. There was almost half reduction of patients during the emergency response period. There was no significant difference in proportion of gender and mean of age between patients in the control group and the COVID group. During the emergency response period, there was significant increases in the proportions of patients experiencing low energy injuries (38.0\% vs. $30.8 \%$ ), injuries occurring at home (34.0\% vs. $23.8 \%)$, and surgically treated closed fractures ( $51.8 \%$ vs. $45.3 \%)$, along with decrease of patients' referrals ( $1.6 \%$ vs. $4.1 \%)$. The difference in proportions of fracture type, osteoporotic fractures, and multiple trauma was not significant across the groups.

Conclusions: During the COVID-19 emergency response period in DIY, there were nearly half reduction $(47.68 \%)$ of patients with fractures, increased proportion of patients injured at home, reduced proportion of patients referred to another hospital, and increased proportion of surgically treated closed fractures. The knowledge about this epidemiological trend may help in developing preventive programs and treatment policy for fractures and other injuries during the current pandemic.

\section{Introduction}

In the end of 2019, a new coronavirus was identified as a cause of a severe respiratory system disease in Wuhan, China [1]. The World Health Organization (WHO) named the disease as Coronavirus Disease 2019 (COVID-19) and later, declared it as a global pandemic on March 11 $11^{\text {th }}, 2020$ [2,3]. On March $13^{\text {th }}, 2020$, the first confirmed case in Yogyakarta Special Region (Daerah Istimewa Yogyakarta/DIY) was announced [4]. Shortly thereafter, the governor of DIY announced the COVID-19 emergency response period, lasting from March $20^{\text {th }}$ until May $29^{\text {th }}, 2020$ which could be extended whenever required [5].

To reduce the disease transmission, people were appealed to do some preventive measures, such as hand hygiene, postpone unnecessary travel, stay at home, and physical distancing [6,7]. The schools were closed and people should work from home whenever possible [8]. 
The changes of lifestyle and mobility during the COVID-19 pandemic have been proven to influence the epidemiology of traumatic fractures. Worldwide, many studies had reported significant reduction in fracture or trauma cases [9-14]. The epidemiological characteristics of traumatic fractures were changed during the COVID-19 pandemic: there were higher patients' average age, with an increase in the proportion of home/domestic accidents, osteoporotic fractures, and fractures caused by low energy trauma $[9,10,15,16]$. The surgeries performed for fractures or other trauma cases was also seen decreased during COVID-19 pandemic period [12,16].

Even though it is useful for developing preventive measures and treatment strategies, the epidemiological information and studies of traumatic fractures in Indonesia are still rare. Moreover, there were still no data found during the COVID-19 pandemic emergency period in DIY. Therefore, this study aimed to investigate the traumatic fractures' epidemiology in DIY during the COVID-19 early emergency response period and compare the data with the similar period in the previous year.

\section{Methods}

This was a comparative-retrospective study, involving five secondary referral and one tertiary referral hospitals in Yogyakarta Special Province: Yogyakarta Regional Public Hospital, Wates Regional Public Hospital, Wonosari Regional Public Hospital, Panembahan Senopati Bantul Regional Public Hospital, Universitas Gadjah Mada Academic Hospital, and Dr. Sardjito General Hospital. This study was approved by the Medical and Health Research Ethics Committee Faculty of Medicine, Public Health and Nursing Universitas Gadjah Mada.

We included all patients who presented to the emergency departments or orthopedic clinics who were then diagnosed with new onset ( $<1$ week) fractures based on history clinical, and radiological examinations. The fractured bones included in this study were: clavicle, scapula, humerus, radius, ulna, hand, spine, pelvic, femur, tibia, fibula, and foot. For the COVID group (during the pandemic period), we included all patients who presented to the hospital from $20^{\text {th }}$ March $-29^{\text {th }}$ May 2020. For the control group, the period was from $1^{\text {st }}$ April - $10^{\text {th }}$ June 2019.

We excluded the patients with pathological fractures due to bone tumors (primary and metastatic), genetic bone abnormalities, unhealed previous fractures (poor union or non-union), periprosthetic fractures, and patients with data missing from their medical records.

The collected data included the sociodemographic characteristics of the patients (age and gender), mechanisms of injury, injury location, fractured bone, type of fracture (closed/open fracture), concurrent fracture, osteoporotic fracture, multiple trauma, hospital stay duration, referral, treatment, and patients who refused recommended surgery or inpatient care. The data were obtained from the medical records.

We categorized the mechanisms of injury as fall from standing height, fall from height $<1 \mathrm{~m}$, fall from height $>1 \mathrm{~m}$, bicycle injury (not involving collision with motor vehicle), motor vehicle accident/MVA (any injuries involving collision with motor vehicle, as the vehicle rider or hit by motor vehicle), others (any 
specific mechanisms of injury such as being hit, trapped, cut, machine-related, etc., not classified in the other groups), and unknown (unspecific mechanisms of injury). We considered fall from standing height, fall from height $<1 \mathrm{~m}$, and the bicycle injury as low energy trauma; where fall from height $>1 \mathrm{~m}$, MVA, and others as high energy trauma. The injury locations were grouped as at home (in the house/living place and the surroundings), road (including the sidewalks), others (school, workplace, sports fields, and other specified places), and unknown.

The fractured bone was documented as clavicle, scapula, humerus, radius and/or ulna, hand, spine, pelvic, femur, tibia and/or fibula, foot, and patella. The patients were stated to have concurrent fracture when they had more than one fracture based on the mentioned bone group. We considered a fracture as an osteoporotic fracture when it fulfilled all the following criteria: 1 . The patient age was more than 50 years old (female)/more than 60 years old (male); 2. Occurred in proximal humerus, distal radius, thoracic/lumbar vertebrae, or proximal femur; and 3 . Caused by a low energy trauma $[17,18]$. The patients were classified as having multiple trauma when they had any injuries involving more than one body region and required treatment from more than one specialist for the injuries [19].

We grouped the treatment as conservative and surgical treatment. For analyzing the treatment, we excluded patients who were referred to another hospital. The patient was classified to receive the surgical treatment for the specified fracture when they received the treatment involving incision with an instrument, performed by orthopedic surgeon, in the operating theatre.

The statistical analysis was performed using SPSS 23.0 (IBM Corp., Armonk, New York). We tested all the numeric variables with Kolmogorov-Smirnov test for the normality of distribution. The difference of mean was analyzed with t-tests for data with normal distribution, and with Mann-Whitney tests for data with abnormal distribution. For categorical variable, we conducted chi-squared and used Fisher exact tests when the expected count was less than five. The $p$-value of $<0.05$ was considered significant.

\section{Results}

During the specified period, we found 1,249 patients presented with fractures of the defined bones: 820 (65.65\%) patients in the control group; 429 (34.35\%) patients in the COVID group. The patients' age ranged from $<1$ year old to 100 years old (mean: $42.49 \pm 19.96$ ). There was no significant difference in mean of age between patients in the control group and the COVID group (control group: $42.64 \pm 24.03$ years; COVID group: $42.20 \pm 23.34$ years; $p=0.886$ ). Three patients from the COVID group were suspected to be affected by COVID-19. However, all of them were negative on PCR swab test.

There was reduction in the number of all cases caused by any mechanism of injury during the pandemic, although the difference in proportion between the groups was not significant (Table 1). When grouped as low or high energy injury, the proportion of low energy injuries increased during the pandemic period (38.0\% vs $30.8 \% ; p=0.012$ ). However, the high energy injuries were still the main cause of fractures in both groups. 
Table 1 Comparison of mechanism of injury between control and COVID group

\begin{tabular}{|c|c|c|c|c|c|}
\hline \multirow[t]{2}{*}{ Mechanism of injury } & \multicolumn{2}{|c|}{ Control group } & \multicolumn{2}{|c|}{ COVID group } & \multirow[t]{2}{*}{$p$-value } \\
\hline & Frequency & Percentage & Frequency & Percentage & \\
\hline Fall from standing height & 193 & $23.5 \%$ & 119 & $27.7 \%$ & \multirow[t]{7}{*}{0.102} \\
\hline Fall from a low height & 24 & $2.9 \%$ & 22 & $5.1 \%$ & \\
\hline Bicycle injury & 26 & $3.2 \%$ & 15 & $3.5 \%$ & \\
\hline Fall from height $>1 \mathrm{~m}$ & 57 & $7.0 \%$ & 33 & $7.7 \%$ & \\
\hline MVA & 379 & $46.2 \%$ & 180 & $42.0 \%$ & \\
\hline Others & 111 & $13.5 \%$ & 42 & $9.8 \%$ & \\
\hline Unknown & 30 & $3.7 \%$ & 18 & $4.2 \%$ & \\
\hline
\end{tabular}

COVID, Coronavirus Disease; MVA, motor vehicle accident

The COVID-19 pandemic has significantly influenced the injury location, where the proportion of injuries at home increased and the injuries outside home decreased ( $p=0.001$ ) (Fig 1.). The road remained the main location where the injuries occur.

The total fractures found in the current study was 1,428 with $945(66.2 \%)$ in the control group and 483 (33.8\%) in the COVID group. Most patients (1,118 patients or $89.5 \%)$ had a fracture, while the rest had concurrent fractures: 103 patients $(8.2 \%)$ had two fractures, 19 patients $(1.5 \%)$ had three fractures, and nine patients had four or more fractures $(0.7 \%)$. During the pandemic period, the total of bone fractures was decreased in frequency by $30 \%$ or more (Table 2 ).

Table 2 Comparison of fractured bone between control and COVID group 


\begin{tabular}{|llllll|}
\hline \multirow{2}{*}{ Fractured bone } & \multicolumn{2}{l}{ Control group } & \multicolumn{2}{l}{ COVID group } & \multirow{2}{*}{ p-value } \\
\cline { 2 - 5 } & Frequency & Percentage & Frequency & Percentage & \\
\cline { 1 - 4 } Clavicle & 80 & $8.5 \%$ & 45 & $9.3 \%$ & \multirow{2}{*}{0.597} \\
\cline { 1 - 4 } Scapula & 10 & $1.1 \%$ & 6 & $1.2 \%$ & \\
\hline Humerus & 76 & $8.0 \%$ & 50 & $10.4 \%$ & \\
\hline Radius and/or Ulna & 226 & $23.9 \%$ & 115 & $23.8 \%$ \\
\hline Hand & 124 & $13.1 \%$ & 47 & $9.7 \%$ \\
\hline Spine & 34 & $3.6 \%$ & 17 & $3.5 \%$ \\
\hline Pelvic & 19 & $2.0 \%$ & 12 & $2.5 \%$ \\
\hline Femur & 141 & $14.9 \%$ & 80 & $16.6 \%$ \\
\hline Tibia and/or Fibula & 132 & $14.0 \%$ & 55 & $11.4 \%$ \\
\hline Foot & 93 & $9.8 \%$ & 49 & $10.1 \%$ \\
\hline Patella & 10 & $1.1 \%$ & 7 & $1.4 \%$ \\
\hline
\end{tabular}

The COVID-19 pandemic has caused more than half reduction in open fracture cases (181 patients in the control group; 84 patients in the COVID group). The proportion was reduced by $1.8 \%$ ( $19.2 \%$ in the control group vs 17.4 in the COVID group), but the difference was not statistically significant $(p=0.418)$. The five most frequently affected bones were: hand (38.9\%), foot (22.3\%), tibia/fibula (16.6\%), femur (9.1\%), and radius/ulna $(8.7 \%)$.

Our study revealed $189(15.1 \%)$ patients suffering osteoporotic fractures. The proportion of osteoporotic fractures was also not significantly different between the control and COVID groups $(15.4 \%$ in the control group; $14.7 \%$ in the COVID group; $p=0.750$ ). Most patients suffering osteoporotic fractures were women (81.0\%).

There were almost $60 \%$ decrease of patients who presented with multiple trauma during the COVID pandemic period, compared to the pre-pandemic period (30 patients in the COVID group; 74 patients in the control group). The proportion of patients experiencing multiple trauma with fracture were also less in COVID pandemic period although the difference was not significant $(7.0 \%$ in COVID group; $9.0 \%$ in control group; $p=0.217)$.

During the pandemic period, 295 (68.8\%) patients received inpatient care. The proportion was slightly higher compared to the control period $(64.1 \%, 526$ patients), although the difference was not significant $(p=0.102)$. For the patients receiving the inpatient care, the mean of hospital stay duration was slightly higher in the control group than in the COVID group ( $4.91 \pm 3.75$ days vs $4.39 \pm 3.45$ days, $p=0.008)$. In 
the control period, the proportion of patients who needed to be referred to another hospital was significantly higher than in the COVID period $(4.1 \%$ vs $1.6 \% ; p=0.018)$.

About $10 \%$ of the patients (82 patients in control group, 46 patients in COVID group) refused to receive recommended inpatient care and/or to receive operative treatment. The proportion was not statistically different between the control and the COVID groups (10.0\% in control group; $10.7 \%$ in COVID group; $p=$ $0.689)$.

There were more fractures treated surgically during the COVID period compared to the control period, although the difference was not significant $(56.2 \%$ vs $52.7 \%, p=0.212)$. However, the difference of the proportion of closed fractures treated surgically vs. conservatively was significant, with more proportion of fractures treated surgically during pandemic period $(51.8 \%$ vs $45.3 \%, p=0.038)$.

\section{Discussion}

We found several impacts of the COVID-19 pandemic on the epidemiology of fractures in our region. As seen worldwide, the total of patients with fractures were reduced. In our study, the reduction was $47.68 \%$. The amount of reduction was similar to a study in China (reduction of $46.74 \%$ ) but lower than the study in Italy (reduction of $73.8 \%$ ) $[9,10]$.

While some studies found increases in the patients' mean age during the pandemic period $[9,10]$, our study did not demonstrate a significant difference in the patients' age across the period groups. The proportions of osteoporotic fractures were not different as well. These findings might be caused by the fear of elderly being infected by COVID-19 virus in the hospital, since they have more risks to develop severe disease when getting infected $[10,20]$. The recommendation to not go to the health facilities unless urgent might also lead to the reluctance of elder people and people with osteoporotic fractures to go to the hospital [21].

This study reveals a transition of the mechanism of injury towards the low energy injury. Additionally, this pandemic contributes to more injuries occurring at home. These findings can be explained by the facts that people spent more time at home, that contains several hazards to low energy injury such as slip or trip on steps or in the bathroom [22]. Consequently, more social education to increase the safety at home is needed to prevent any injuries at home during the pandemic.

In our study, the MVA was still the number one cause of fractures during the pandemic period, although the number of cases was reduced $52.5 \%$. However, the decrease was much less compared to the previous studies in Italy and China where the reduction of MVA cases was $79.6 \%$ and $88.9 \%$, respectively $[9,13]$. Less reduction of case numbers and the dominance of MVA in the pandemic period might be associated by less restriction in the mobility of people in Indonesia and less compliance of Indonesian people to stay at home and maintain safe social distancing. In contrast to China and Italy, Indonesia was not applying a lockdown due to the economic considerations $[23,24]$. The domination of MVA even during COVID-19 pandemic necessitates more prevention to decrease the high case number. People should be more 
educated to drive/ride motorcycle safely, i.e. using helmets, not riding/driving when sleepy, limitation of the speed, etc.

Previous studies demonstrate significant reduction in the proportion of open fractures and concurrent fractures, along with reduction in the Injury Severity Score (ISS) in patients with multiple trauma [9]. However, our study cannot demonstrate similar results. It is known that the occurrence of open fractures, concurrent fractures and multiple trauma were associated with high energy injuries [25-27]. In our study, the reduction in percentage of high energy injuries during the pandemic period was relatively small, and the high energy injury remains the main cause of people presenting to the ED with fractures. In contrast, the previous study reported significantly more reduction in the proportion of high energy injuries [9].

The current study found that the total number of surgically treated fractures was reduced by $44.2 \%$. This finding was similar to the previous study in China where the surgically treated fractures were reduced to almost 50\% [9]. For all trauma cases, studies in London and Pakistan reported the number of surgeries for trauma were reduced about $30 \%$ and $40 \%$, respectively $[12,16]$.

This study shows a higher proportion of closed fractures treated surgically during the pandemic. There were several possibilities to explain this finding. First, patients with closed fracture with minimal displacement caused by low energy trauma did not go to the hospital because they thought the injury would not cause fractures. This will decrease the number of fractures which were usually treated conservatively. Second, due to the decrease of the number of surgeries because of the decreased patient number and postponed elective procedures, more staff and facilities were available for surgery.

There are several limitations of this study. First was its retrospective design. Second, for osteoporotic fractures, we did not use the bone mineral density value that would be more accurate to see the extent of osteoporosis. Third, we only included the patients from public and academic hospitals. We had no data from private hospitals.

We recommend future studies to examine the epidemiology of fractures with a longer time period and involving more variety of treatment centers to add to the strength of the study and so that we can see the trends during the year. Because this research only included the acute fractures, further study is recommended to investigate the neglected fractures or injuries other than fractures.

\section{Conclusions}

The COVID-19 pandemic has led to several changes in fracture epidemiology. During the COVID-19 early emergency response period in DIY, there was almost half reduction (47.68\%) of patients with fractures who presented to the hospital. The proportion of fractures due to low energy injury increased, as well as the proportion of patients being injured at home. There was a reduction in the proportion of patients referred to another hospital and an increase in the proportion of surgically treated closed fractures. The knowledge about this epidemiological trend may help in developing preventive programs and treatment policy for fractures and other injuries during the current pandemic. 


\section{Abbreviations}

COVID-19

Coronavirus Disease 2019

DIY

Daerah Istimewa Yogyakarta (Yogyakarta Special Region)

WHO

World Health Organization

MVA

Motor Vehicle Accident

ISS

Injury Severity Score

\section{Declarations}

\section{Ethics approval}

This study was approved by the Medical and Health Research Ethics Committee (MHREC) of the Faculty of Medicine, Public Health and Nursing Universitas Gadjah Mada (No. KE/FK/0813/EC/2020, Date of approval July 22, 2020)

\section{Consent to participate}

Not applicable

\section{Consent for publication}

Not applicable

\section{Availability of data and materials}

All data generated or analyzed during this study are included in this published article. The raw data are available from the corresponding author on reasonable request.

\section{Competing interests}

The authors have no relevant financial or non-financial interests to disclose.

\section{Funding}

No funding was received for conducting this study.

\section{Authors' contributions}


Conceptualization, methodology, and supervision: Luthfi Hidayat; data collection and analysis: Acep Eko Budi Purwanta, Marda Ade Saputra, Eko Sumardiyono, Aditya Fuad Robby Triangga; manuscript writing: Bernadeta Fuad Paramita Rahayu, Rosyad Nur Khadafi, Luthfi Hidayat

\section{Acknowledgements}

Not applicable

\section{References}

1. Guan W, Ni Z, Hu Y, Liang W, Ou C, He J, et al. Clinical characteristics of Coronavirus Disease 2019 in China. N Engl J Med. 2020;382(18):1708-20.

2. World Health Organization. WHO Director-General's remarks at the media briefing on 2019-nCoV on 11 February. https://www.who.int/dg/speeches/detail/who-director-general-s-remarks-at-the-mediabriefing-on-2019-ncov-on-11-february-2020 (2020). Accessed 6 July 2020.

3. World Health Organization: WHO Director-General's opening remarks at the media briefing on COVID19-11. March 2020. https://www.who.int/dg/speeches/detail/who-director-general-s-openingremarks-at-the-media-briefing-on-covid-19-11-march-2020 (2020). Accessed 6 July 2020.

4. Manusubroto W, Wicaksono AS, Tamba DA, et al. Neurosurgery Services in Dr. Sardjito General Hospital, Yogyakarta, Indonesia, During the COVID-19 Pandemic: Experience from a Developing Country. World Neurosurg. 2020;140:e360-6. https://doi.org/10.1016/j.wneu.2020.05.124.

5. Pemerintah Daerah DIY: Keputusan Gubernur Daerah Istimewa Yogyakarta Nomor 65/KEP/2020 Tentang Penetapan Status Tanggap Darurat Bencana Corona Virus Disease 2019 (COVID-19) di Daerah Istimewa Yogyakarta. In: Dokumen Publik Perkembangan COVID-19. Official website Pemerintah Daerah DIY. 2020. https://corona.jogjaprov.go.id/files/33/Covid19/8/KepGub-DIY-No-65KEP-2020-ttg-Penetapan-Status-Tanggap-Darurat-Bencana-COVID-19-di-DIY.pdf. Accessed 7 July 2020.

6. Pemerintah Daerah DIY: Surat Edaran Nomor 1/SE/III/2020 Tentang Pelaksanaan Status Tanggap Darurat Bencana Corona Virus Disease (COVID-19) di Daerah Istimewa Yogyakarta. In: Dokumen Publik Perkembangan COVID-19. Official website Pemerintah Daerah DIY. 2020.

https://corona.jogjaprov.go.id/files/33/Covid19/11/SE-Gubernur-tentang-Status-Tanggap-daruratBencana-Covid-19-di-DIY.pdf. Accessed 7 July 2020.

7. Djalante R, Lassa J, Setiamarga D, et al. Review and analysis of current responses to COVID-19 in Indonesia: period of January to March 2020. Progress in Disaster Science 2020; 100091. http://dx.doi.org/10.1016/j.pdisas.2020.100091.

8. Herdiana D. Social distancing: Indonesian policy response to the Corona Virus Disease 2019 (COVID19) J IImu Adm Media Pengemb Ilmu dan Prakt Adm. 2020;17(1):93-110.

9. Lv H, Zhang Q, Yin Y, Zhu Y, Wang J, Hou Z, et al. Epidemiologic characteristics of traumatic fractures during the outbreak of coronavirus disease 2019 (COVID-19) in China: a retrospective and 
comparative multi-center study. Injury. 2020;51(8):1698-704.

10. Luceri F, Morelli I, Accetta R, Mangiavini L, Maffulli N, Peretti GM. Italy and COVID-19: the changing patient flow in an orthopedic trauma center emergency department. J Orthop Surg Res. 2020;15(1):323. https://doi.org/10.1186/s13018-020-01816-1.

11. Hernigou J, Morel X, Callewier A, Bath O, Hernigou P. Staying home during “COVID-19” decreased fractures, but trauma did not quarantine in one hundred and twelve adults and twenty eight children and the "tsunami of recommendations" could not lockdown twelve elective operations. Int Orthop. 2020;44(8):1473-80. https://doi.org/10.1007/s00264-020-04619-5.

12. Park C, Sugand K, Nathwani D, Bhattacharya R, Sarraf KM. Impact of the COVID-19 pandemic on orthopedic trauma workload in a London level 1 trauma center: the "golden month. Acta Orthop. 2020;91(5):556-61. https://doi.org/10.1080/17453674.2020.1783621.

13. Dolci A, Marongiu G, Leinardi L, Lombardo M, Dessì G, Capone A. The epidemiology of fractures and musculo-skeletal traumas during COVID-19 lockdown: a detailed survey of 17,591 patients in a wide Italian metropolitan area. Geriatr Orthop Surg Rehabil. 2020;11:215145932097267. https://doi.org/10.1177/2151459320972673.

14. Turgut A, Arli H, Altundag U, Hancioglu S, Egeli E, Kalenderer O. Effect of COVID-19 pandemic on the fracture demographics: data from a tertiary care hospital in Turkey. Acta Orthop Traumatol Turc. 2020;54(4):355-63. https://doi.org/10.5152/j.aott.2020.20209.

15. Nuñez JH, Sallent A, Lakhani K, Guerra-Farfan E, Vidal N, Ekhtiari S, et al. Impact of the COVID-19 pandemic on an emergency traumatology service: experience at a tertiary trauma centre in Spain. Injury. 2020;51(7):1414-8. https://doi.org/10.1016/j.injury.2020.05.016.

16. Hashmi PM, Zahid M, Ali A, Naqi H, Pidani AS, Hashmi AP, et al. Change in the spectrum of orthopedic trauma: effects of COVID-19 pandemic in a developing nation during the upsurge: a cross-sectional study. Ann Med Surg. 2020;60:504-8. https://doi.org/10.1016/j.amsu.2020.11.044.

17. Campion JM, Maricic MJ. Osteoporosis in men. Am Fam Physician. 2003;67(7):1521-6.

18. Yoo J-H, Moon S-H, Ha Y-C, Lee DY, Gong HS, Park SY, et al. Osteoporotic fracture: 2015 position statement of the Korean Society for Bone and Mineral Research. J Bone Metab. 2015;22(4):175. https://doi.org/10.11005/jbm.2015.22.4.175.

19. Butcher N, Balogh ZJ. The definition of polytrauma: the need for international consensus. Injury. 2009;40(Suppl 4):12-22. https://doi.org/10.1016/j.injury.2009.10.032.

20. Osama T, Pankhania B, Majeed A. Protecting older people from COVID-19: should the United Kingdom start at age 6? J R Soc Med. 2020;113(5):169-70.

21. Tarantino U, Cariati I, Tancredi V, Casamassima D, Piccirilli E, lundusi R, et al. State of fragility fractures management during the COVID-19 pandemic. Int J Environ Res Public Health. 2020;17:1-7.

22. Josephson KR, Fabacher DA, Rubenstein LZ. Home safety and fall prevention. Clin Geriatr Med. 1991;7(4):707-32. https://doi.org/10.1016/S0749-0690(18)30515-9.

23. Ren X. Pandemic and lockdown: a territorial approach to COVID-19 in China, Italy and the United States. Eurasian Geogr Econ. 2020;61(4-5):423-34. 
https://doi.org/10.1080/15387216.2020.1762103.

24. Wicaksono RMTAD. Examining the Policies and Priorities of the Indonesian Government in Response to COVID-19 [Internet]. Pusat Penelitian Politik - Lembaga IImu Pengetahuan Indonesia. 2020 [cited 26 December 2020]. Available from: http://www.politik.lipi.go.id/kolom/kolom-2/politiknasional/1410-examining-the-policies-and-priorities-of-the-indonesian-government-in-response-tocovid-19.

25. Feichtinger $X$, Kocijan R, Mittermayr R, Baierl A, Schanda J, Wakolbinger R, et al. Fracture patterns in patients with multiple fractures: the probability of multiple fractures and the most frequently associated regions. Eur J Trauma Emerg Surg. 2020;46(5):1151-8. http://dx.doi.org/10.1007/s00068-019-01087-4.

26. Reihani H, Pirazghandi H, Bolvardi E, Ebrahimi M, Pishbin E, Ahmadi K, et al. Assessment of mechanism, type and severity of injury in multiple trauma patients: a cross sectional study of a trauma center in Iran. Chinese J Traumatol. 2017. http://dx.doi.org/10.1016/j.cjtee.2016.02.004.

27. Zalavras CG, Patzakis MJ. Open fractures: evaluation and management. J Am Acad Orthop Surg. 2003;11(3):212-9. https://doi.org/10.5435/00124635-200305000-00008.

\section{Figures}

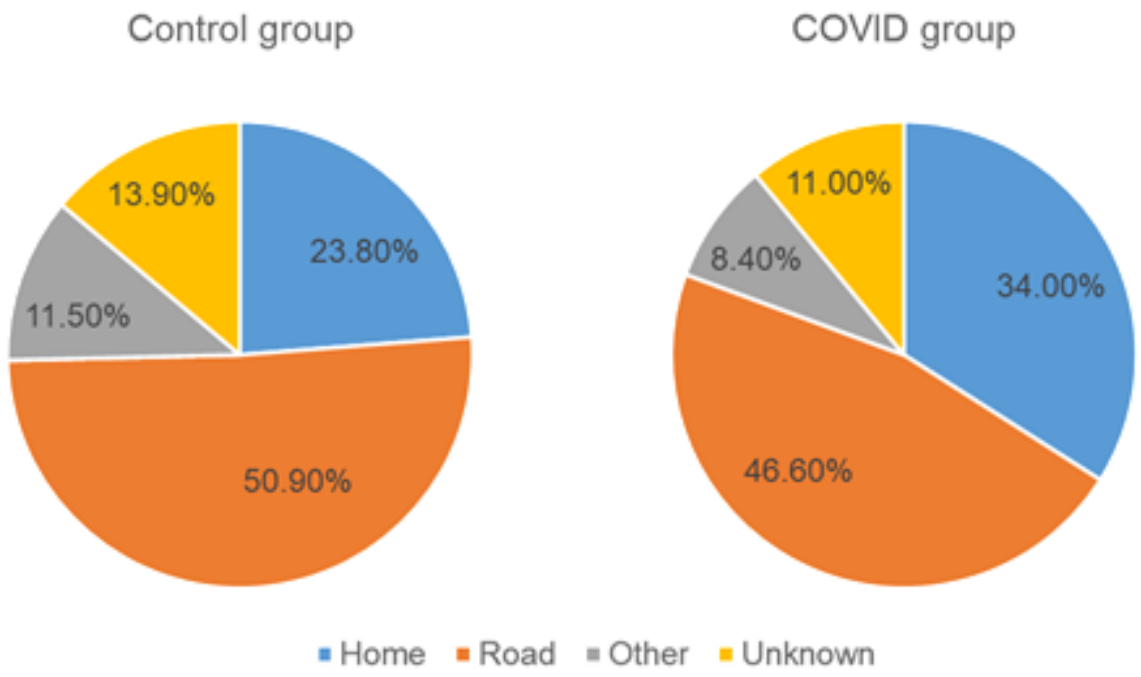

\section{Figure 1}

Comparison of injury location between control and COVID group 